\title{
Identification of potential targets for diallyl disulfide in human gastric cancer MGC-803 cells using proteomics approaches
}

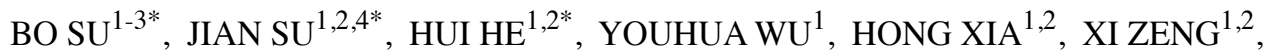

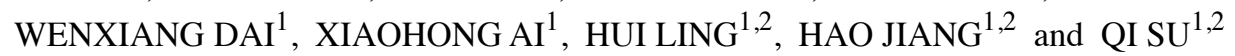 \\ ${ }^{1}$ Center for Gastric Cancer Research of Hunan Province, First Affiliated Hospital, ${ }^{2}$ Key Laboratory of Cancer Cellular and \\ Molecular Pathology of Hunan Provincial University, Cancer Research Institute, ${ }^{3}$ Key Laboratory for Pharmacoproteomics \\ of Hunan Provincial University, Institute of Pharmacy and Pharmacology, ${ }^{4}$ Department of Pathology, \\ Second Affiliated Hospital, University of South China, Hengyang, Hunan 421001, P.R. China
}

Received November 27, 2014; Accepted February 26, 2015

DOI: $10.3892 /$ or.2015.3859

\begin{abstract}
Diallyl disulfide (DADS) is characterized as an effective agent for the prevention and therapy of cancer, however, mechanisms regarding its anticancer effects are not fully clarified. In the present study, we compared the protein expression profile of gastric cancer MGC- 803 cells subjected to DADS treatment with that of untreated control cells to explore potential molecules regulated by DADS. Using proteomic approaches, we identified 23 proteins showing statistically significant differences in expression, including 9 upregulated and 14 downregulated proteins. RT-PCR and western blot analysis confirmed that retinoid-related orphan nuclear receptor $\alpha(\mathrm{ROR} \alpha)$ and $\mathrm{nM} 23$ were increased by DADS, whereas LIM kinase-1 (LIMK1), urokinase-type plasminogen activator receptor (UPAR) and cyclin-dependent kinase-1 (CDK1) were decreased. DADS treatment and knockdown of uPAR caused suppression of ERK/Fra-1 pathway, downregulation of urokinase-type plasminogen activator (uPA), matrix metalloproteinase-9 (MMP-9) and vimentin, and upregulation of tissue inhibitor of metalloproteinase-3 (TIMP-3) and E-cadherin, concomitant with inhibition of cell migration and invasion. Moreover, knockdown of uPAR potentiated the effects of DADS on MGC-803 cells. These data demonstrate that downregulation of UPAR may partially be responsible for DADS-induced inhibition of ERK/Fra-1 pathway, as well as cell migration and invasion. Thus, the discovery of
\end{abstract}

Correspondence to: Professor Qi Su or Professor Hao Jiang, Key Laboratory of Cancer Cellular and Molecular Pathology of Hunan Provincial University, Cancer Research Institute, University of South China, Chang Sheng Xi Avenue 28, Hengyang, Hunan 421001, P.R. China

E-mail: suqi1945@163.com

E-mail: jhao16859@163.com

${ }^{*}$ Contributed equally

Key words: gastric cancer, diallyl disulfide, potential targets, proteomics, invasion
DADS-induced differential expression proteins is conducive to reveal unknown mechanisms of DADS anti-gastric cancer.

\section{Introduction}

Gastric cancer, one of the most common human malignant tumors, accounts for the first leading cause of gastrointestinal cancer-related mortality worldwide (1), particularly in China (2). Chemotherapy has been shown to increase overall survival in patients with early gastric cancer after surgery over the years, yet survival in advanced and metastatic stages has not significantly improved (3).

Diallyl disulfide (DADS) is one of the organosulfur compounds that derive from Allium vegetables, such as garlic. Laboratory evidence has revealed that DADS exerts multiple antitumor effects on a variety of tumors by suppression of cell proliferation, angiogenesis or invasion, induction of apoptosis or differentiation $(4,5)$, without gross toxicity based on the experiments in vivo $(6,7)$. Therefore, as a putative anticancer agent to inhibit cancer cell growth and invasion, DADS has good prospects for clinical application of adjuvant therapy.

Many studies have shown that diverse molecular mechanisms are implicated in the suppressive effect of DADS on tumor growth $(4,5)$. In particular, a few studies suggest that DADS inhibits cancer cell invasion through reducing the expression and activities of matrix metalloproteinases (MMPs) $(8,9)$. However, the underlying mechanisms are still largely unknown. Thus, potential molecules regulated by DADS remain to be explored to elucidate its inhibitory effect on tumor growth, particularly metastasis.

We have previously demonstrated that DADS induces G2/M phase cell cycle arrest in gastric cancer cell lines via ATR/Chk1/Cdc25C/cyclin B1 signaling pathway, accompanied with an increase in Chk1 phosphorylation $(10,11)$ and a decrease in Cdc25C expression through activation of p38 (12). In addition, DADS induced cell differentiation by downregulating ERK signaling pathway (13). Our recent study showed that DADS suppresses gastric cancer growth and induces apoptosis by upregulation of miRNA-200b and miRNA-22 (14).

To further explore potential molecular targets affected by DADS in gastric cancer, we screened and obtained 
some proteins through proteomics research approaches, which showed significantly differential expression between DADS-treated and untreated gastric cancer cells in the present study. The expression changes of retinoid-related orphan nuclear receptor $\alpha(\operatorname{ROR} \alpha), \mathrm{nM} 23$, cyclin-dependent kinase-1 (CDK1), urokinase-type plasminogen activator receptor (UPAR) and LIM kinase-1 (LIMK1) were verified in subsequent experiments. We further explored the effects of DADS on the ERK/Fra-1 pathway, as well as the invasion and epithelial-mesenchymal transition (EMT)-associated protein expression. We proposed that DADS-induced suppression of migration and invasion of gastric cancer cells may be in part, due to downregulation of the UPAR and the ERK/Fra-1 pathway.

\section{Materials and methods}

Reagents and antibodies. DADS (purity 80\%, the remaining $20 \%$ being diallyl trisulfide and diallyl sulfide), purchased from Fluka Co. (Milwaukee, WI, USA), was dissolved in Tween-80 and stored at $-20^{\circ} \mathrm{C}$ after a 100 -fold dilution with saline. The primary antibodies for LIMK1 (ab81046), uPAR (ab89932), Fra-1 (ab117951), E-cadherin (ab40772), MMP-9 (ab38898), TIMP-3 (ab39184) and vimentin (ab92547) were purchased from Abcam (Abcam, Cambridge, UK). The antibody against uPA (17968-1-AP) was purchased from ProteinTech (ProteinTech Group, Chicago, IL, USA). The primary antibodies for ROR $\alpha$ (sc-6062), nM23-H1 (sc-343), CDK1 (sc-54), ERK1/2 (sc-135900), p-ERK1/2 (sc-292838) and $\beta$-actin (sc-47778) and horseradish peroxidase (HRP)-conjugated secondary antibodies were purchased from Santa Cruz Biotechnology (Santa Cruz, CA, USA).

Cell culture and cell line establishment. Human gastric cancer cell line MGC-803 was obtained from the Cancer Research Institute, Xiangya Medical College, Center South University in China. The cells were cultured in RPMI-1640 medium (Gibco, Life Technologies, Vienna, Austria), supplemented with 10\% heat-inactivated fetal bovine serum (FBS; Life Technologies, USA), $100 \mu \mathrm{g} / \mathrm{ml}$ streptomycin, and $100 \mathrm{U} / \mathrm{ml}$ penicillin $\mathrm{G}$ (Invitrogen, Carlsbad, CA, USA) in a humidified atmosphere of $5 \% \mathrm{CO}_{2}$ and $95 \%$ air at $37^{\circ} \mathrm{C}$. MGC-803 cells $\left(2 \times 10^{6}\right)$ in the logarithmic growth phase were untreated or treated with $30 \mathrm{mg} / \mathrm{l}$ DADS. To establish the stable uPAR-interfering cell lines, three pcDNA ${ }^{\mathrm{TM}}$ 6.2-GW/EmGFPmiR uPAR-microRNA (miR)-expressing plasmids were constructed by Invitrogen Corporation. Sequences of DNA oligomers inserted into pcDNA $^{\mathrm{TM}}$ 6.2-GW/EmGFPmiR were as follows: miR1 sense, 5'-TGC TGA AGT CTA ACC CAC ACA CAA CCG TTT TGG CCA CTG ACT GAC GGT TGT GTG GGT TAG ACT T-3' and antisense, 5'-CCT GAA GTC TAA CCC ACA CAA CCG TCA GTC AGT GGC CAA AAC GGT TGT GTG TGG GTT AGA CTT C-3'; miR2 sense, 5'-TGC TGA TAG GTG ACA GCC CGG CCA GAG TTT TGG CCA CTG ACT GAC TCT GGC CGC TGT CAC CTA T-3' and antisense, 5'-CCT GAT AGG TGA CAG CGG CCA GAG TCA GTC AGT GGC CAA AAC TCT GGC CGG GCT GTC ACC TAT C-3'; miR3 sense, 5'-TGC TGA ATG CAT TCG AGG TAA CGG CTG TTT TGG CCA CTG ACT GAC AGC CGT TAT CGA ATG CAT T-3' and antisense, 5'-CCT GAA TGC ATT CGA TAA
CGG CTG TCA GTC AGT GGC CAA AAC AGC CGT TAC CTC GAA TGC ATT C-3'; MGC-803 cells were transfected with uPAR-miR expressing plasmid and empty vector (control) using Lipofectamine 2000 reagent (Invitrogen), following the instructions of the manufacturer. The transfected cells were selected with blasticidin (Invitrogen) until the stable transgene expression during culture maintenance. The expression levels of UPAR in stable cell lines were evaluated by reverse transcription-polymerase chain reaction (RT-PCR) and western blot analysis to confirm the knockdown efficacy.

Preparation of protein samples for two-dimensional electrophoresis (2-DE). DADS-treated and -untreated cells were harvested and lysed in lysis buffer containing $8 \mathrm{M}$ urea, 4\% CHAPS, $40 \mathrm{mM}$ Tris, $1 \%$ DDT, $0.5 \%$ immobilized $\mathrm{pH}$ gradient (IPG) buffer (all from Amersham Biosciences) and protease inhibitor mixture (Roche Molecular Biochemicals). The samples were mixed and incubated on ice for $30 \mathrm{~min}$ and then centrifuged at 15,000 rpm for $30 \mathrm{~min}$. The supernatant was transferred to a fresh tube and stored in $-80^{\circ} \mathrm{C}$ until use. The total protein concentration was measured according to the Bradford protein assay method with bovine serum albumin as standard.

2-DE. 2-DE was carried out to separate proteins from DADS-treated and -untreated cells of three independent experiments. Protein $(200 \mu \mathrm{g})$ was taken from each extract then dissolved in a $320 \mu \mathrm{l}$ rehydration solution (8 $\mathrm{M}$ urea, $4 \%$ CHAPS, 65 mM DDT, $0.5 \%$ IPG buffer and a trace of bromophenol blue) and placed at room temperature for $40 \mathrm{~min}$, then loaded to $18 \mathrm{~cm}$ IPG strips containing a wide-range of $\mathrm{pH}$ gradient 3-10 (Amersham Biosciences). Rehydration and isoelectric focusing (IEF) were performed at $20^{\circ} \mathrm{C}$ for $12 \mathrm{~h}$ at $50 \mathrm{~V}$, followed by $50 \mu \mathrm{A} / \mathrm{IPG}$ strip, $500 \mathrm{~V}$ for $1 \mathrm{~h}, 1,000 \mathrm{~V}$ for $1 \mathrm{~h}, 8,000 \mathrm{~V}$ for $4 \mathrm{~h} 30 \mathrm{~min}$ using an IPGphor (Amersham Biosciences). Following IEF, the IPG strips were equilibrated with equilibration buffer (6 $\mathrm{M}$ urea, $2 \%$ sodium dodecyl sulfate, $50 \mathrm{mM}$ Tris- $\mathrm{HCl}, \mathrm{pH} \mathrm{8.8,30 \%} \mathrm{glycerol} \mathrm{and} \mathrm{1 \%} \mathrm{DTT)}$ for $15 \mathrm{~min}$, and then they were put in the same solution, with $2.5 \%$ iodoacetamide replacing DTT, for an additional $15 \mathrm{~min}$ with gentle shaking. The equilibrated strips were transferred to the top of $12.5 \%$ SDS PAGE gels and embedded in $1 \%$ low-melting agarose containing a trace of bromophenol blue. Electrophoresis was carried out using Ettan DALTsix system (GE Healthcare) at $25 \mathrm{w} / \mathrm{gel}$ for $30 \mathrm{~min}$, and then $17 \mathrm{w} / \mathrm{gel}$ until the bromophenol blue dye reached the bottom of the gel. Then, the gels were fixed (40\% ethanol, $10 \%$ acetic acid) and silver stained using the PlusOne silver staining kit (Amersham Biosciences) as described in the instructions of the manufacturer.

Gel imaging and spot analysis. Gels were scanned using the Molecular Imager Gel Doc XR System and analyzed using the PDQuest system (both from Bio-Rad), according to the protocols provided by the manufacturer. Spot intensities were quantified by calculation of spot volume after normalization of the image using the total spot volume normalization method. Protein spots showing at least a 2.0-fold difference in abundance between control and treatment were considered as differentially expressed. The selected protein spots 
that were statistically analyzed by the Student's t-test with $\mathrm{P}<0.05$ were considered to indicate a statistically significant result.

Mass spectrometry analysis. The excised spots of interest were destained and digested as previously described (15). Briefly, protein spots were destained with $15 \mathrm{mM} \mathrm{K}_{3}\left[\mathrm{Fe}(\mathrm{CN})_{6}\right]$ and $50 \mathrm{mM} \mathrm{Na} 2 \mathrm{~S}_{2} \mathrm{O}_{3}$. Gel pieces were incubated in the digestion solution with $20 \mu \mathrm{g} / \mathrm{ml}$ trypsin (Amresco) for 10-12 h at $37^{\circ} \mathrm{C}$. The tryptic peptide mixture was mixed with $\alpha$-cyano4-hydroxycinnamic acid matrix solution (Sigma-Aldrich, St. Louis, MO, USA). One microliter of the mixture was analyzed by the Voyager System DE-STR 4307 matrix-assisted laser desorption/ionization time of flight mass spectrometer (MALDI-TOF-MS) (Applied Biosystems, Foster City, CA, USA). Protein identification was performed by matching the peptide mass fingerprints against the Swiss-Prot or the NCBInr database with the MS-Fit search program (http://prospector.ucsf.edu/). Molecular weight (Mr) and isoelectric point (pI) of the identified proteins were subsequently compared with the experimental values obtained from the 2-DE image analysis.

Reverse transcription-polymerase chain reaction (RT-PCR). Total RNA was extracted from the cells using TRIzol reagent (Invitrogen). Reverse transcription was carried out using the RT-PCR system and PCR analysis was performed using the GeneAmp PCR kit (Promega, Madison, WI, USA). Primer sequences were as follows: ROR $\alpha$ F, 5'-GTC AGC AGC TTC TAC CTG GAC-3' and R, 5'-GTG TTG TTC TGA GAG TGA AAG GCA CG-3'; nM23 F, 5'-AGG GCA GAC CAC ATT GCT TTT C-3' and R, 5'-GCT GGG AGG AAG CAT TTT TAA TC-3'; $\beta$-actin F, 5'-TCT ACA ATG AGC TGC GTG TGG-3' and R, 5'-GGA ACC GCT CAT TGC CAA TG-3'. For LIMK1 F, 5'-GGG GCA TCA TCA AGA GCA-3' and R, 5'-CCA GGC AGT TGT GGG AGT-3'; $\beta$-actin F, 5'-ACA CTG TGC CCA TCT ACG AGG GG-3' and R, 5'-ATG ATG GAG TTG AAG GTA GTT TCG TGG AT-3'. For uPAR F, 5'-TCA CCT ATT CCC GAA GCC GTT AC-3' and R, 5'-AGA GTG AGC GTT CGT GAG TGC C-3'; $\beta$-actin F, 5'-CCC ACA CTG TGC CCA TCT AC-3' and R, 5'-GCC GGA CTC GTC ATA CTC CT-3'. For CDK1 F, 5'-AGT CAG TCT TCA GGA TGT GCT-3' and R, 5'-TGA CAT GGG ATG CTA GGC TT-3'; $\beta$-actin F, 5'-TGG CAT CCA CGA AAC TAC CT-3' and R, 5'-TCA CCT TCA CCG TTC CAG TT-3'. The PCR products were analyzed on a $2 \%$ agarose gel containing ethidium bromide. The densitometric quantitation of the products was determined using Lab-work analysis software. The ratio of target gene to $\beta$-actin was calculated to obtain the relative fold-changes in gene expression. A DL1000 DNA ladder and a 100 bp DNA ladder were used as the markers (Takara, Dalian, China).

Western blot analysis. For the total protein extraction, the cells were lysed on ice for $30 \mathrm{~min}$ in $0.1 \mathrm{ml}$ lysis buffer [ $10 \mathrm{mmol} / 1$ Tris- $\mathrm{HCl}$ (pH 7.6), $100 \mathrm{mmol} / \mathrm{l} \mathrm{NaCl}, 1 \mathrm{mmol} / \mathrm{l}$ EDTA (pH 8.0), $100 \mu \mathrm{g} / \mathrm{ml}$ PMSF and $1 \mu \mathrm{g} / \mathrm{ml}$ aprotinin]. The cell lysates were centrifuged at $12,000 \mathrm{rpm}$ for $10 \mathrm{~min}$, and the protein contents were determined by the BCA protein assay kit (Pierce, Rockford, IL, USA). The protein extracts were resolved on $12 \%$ SDS-polyacrylamide gels for electrophoresis and transferred onto the PVDF membranes. The membranes were incubated with 5\% skim milk in Tris-buffered saline (TBS) containing $0.1 \%$ Tween-20 for $2 \mathrm{~h}$ at room temperature and then they were incubated with the primary antibody at $4{ }^{\circ} \mathrm{C}$ overnight. After being washed with TBS-T, the membranes were then incubated with the HRP-conjugated secondary antibody $(1: 1,000-2,000)$. The membranes were developed by an enhanced chemiluminescence plus kit (Amersham Biosciences, Buckinghamshire, UK) and bands were visualized on X-ray film (Kodak). The target protein amounts were normalized towards $\beta$-actin quantity using densitometry, and relative fold-changes in protein levels were calculated.

Migration assays. Cell migration was evaluated using the scratch wound assay as previously described (16). Briefly, the cells were cultured to $90 \%$ confluence in a 6-well plate and washed with serum-free RPMI-1640 medium. The cell monolayers were wounded with a $10-\mu l$ plastic pipette tip. After, the cells were untreated or treated with $30 \mathrm{mg} / \mathrm{l}$ DADS, the wound areas were photographed using an inverted microscope. The distance that the cells migrated from the wound edge was measured and a mean value of five independent microscope fields was calculated. The experiments were repeated three times. Migration rates were expressed as ratios between treated vs. control group values or between 24 vs. $0 \mathrm{~h}$ group values.

Invasion assays. Invasion assays were carried out using Transwell $^{\circledR}$ (Corning, Corning, NY, USA) as previously described (16). Matrigel (25 $\mu \mathrm{g})$ (Becton-Dickinson, Bedford, MA, USA) dilution was added to the upside of porous filters (pore size, $8-\mu \mathrm{m}$ ) and allowed to gel at $37^{\circ} \mathrm{C}$ overnight. After the coated filters were rehydrated with $100 \mu \mathrm{l}$ medium, $1 \times 10^{5}$ cells in $200 \mu 1$ serum-free medium supplemented with $0.2 \%$ bovine serum albumin were seeded into the upper part of each chamber, whereas the lower compartments were filled with $500 \mu \mathrm{l}$ of culture medium. The cells were treated or untreated with $30 \mathrm{mg} / 1$ DADS. The invaded cells on the lower membrane surface were fixed with $4 \%$ paraformaldehyde and stained with $0.1 \%$ crystal violet. The experiments were repeated three times. Invasiveness was determined by counting an average number of cells from four microscopic fields/well, and invasion rates were expressed as ratios between treated vs. control group values, or between 24 vs. $0 \mathrm{~h}$ group values.

Statistical analyses. All the results are presented as mean \pm SD or SE of three independent experiments. The Student's t-test and the one-way ANOVA were used to identify statistical significance. A two-sided $\mathrm{P}<0.05$ was considered to indicate a statistically significant result.

\section{Results}

DADS inhibits MGC-803 cell migration and invasion. We first treated cells with 20,30 and $40 \mathrm{mg} / 1$ DADS for $24 \mathrm{~h}$, and examined the effects of DADS on migration and invasion of the gastric cancer MGC-803 cell line. As shown in Fig. 1A and B, DADS reduced migration and invasion rates of the cells in a concentration-dependent manner. These data indicate that treatment with DADS significantly inhibited migration and 
A

$0 \mathrm{~h}$

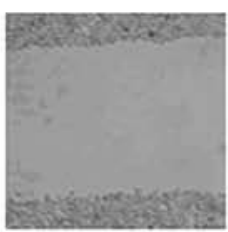

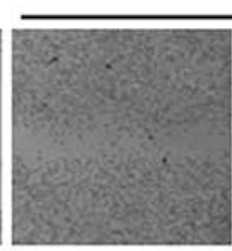

Control
$24 \mathrm{~h}$

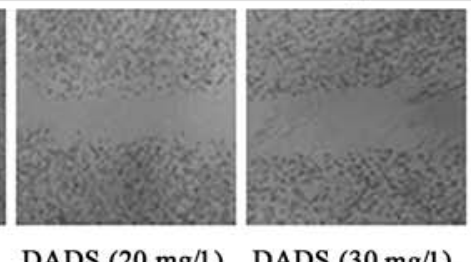

DADS $(20 \mathrm{mg} / 1) \quad$ DADS $(30 \mathrm{mg} / 1)$

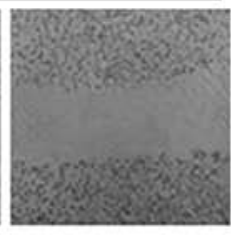

DADS (40 mg/l)

B

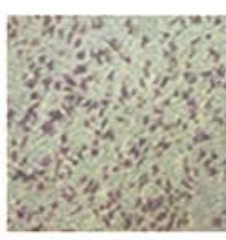

Control

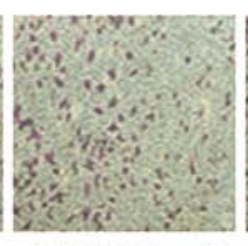

DADS (20 mg/1)

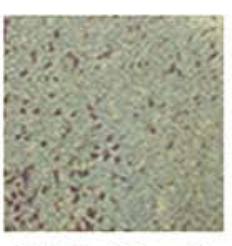

DADS $(30 \mathrm{mg} / 1)$

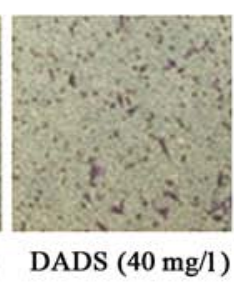

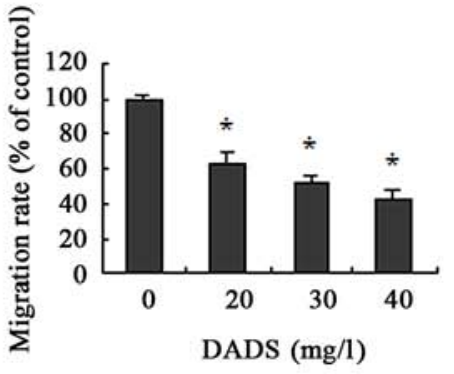

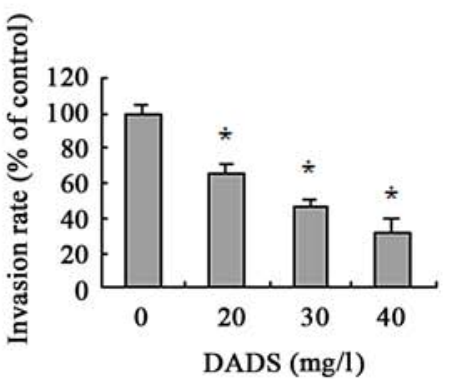

Figure 1. Effects of DADS on migration and invasion of the MGC-803 cells. The MGC803 cells were treated with the indicated DADS concentrations for $24 \mathrm{~h}$. (A) Cell migration was analyzed using the scratch wound assay. The migration rate was expressed as the ratio of the migration distance between treated and untreated cells. (B) The invasion rate was determined by the ratio of the means of the cell numbers between treated and untreated cells. "P<0.05 vs. control. DADS, diallyl disulfide.

A

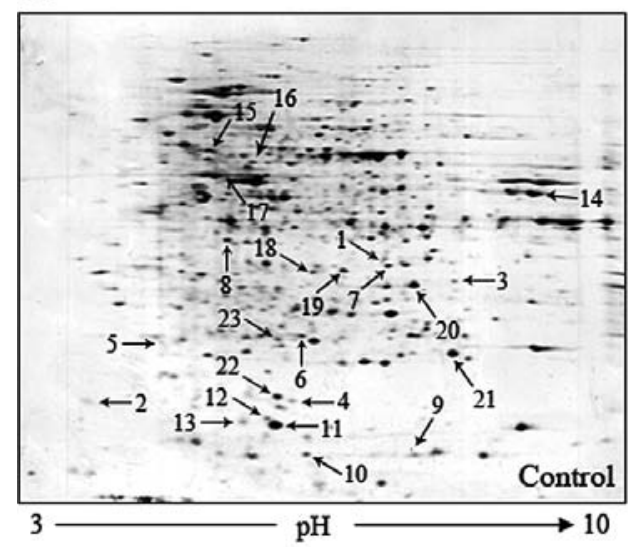

B

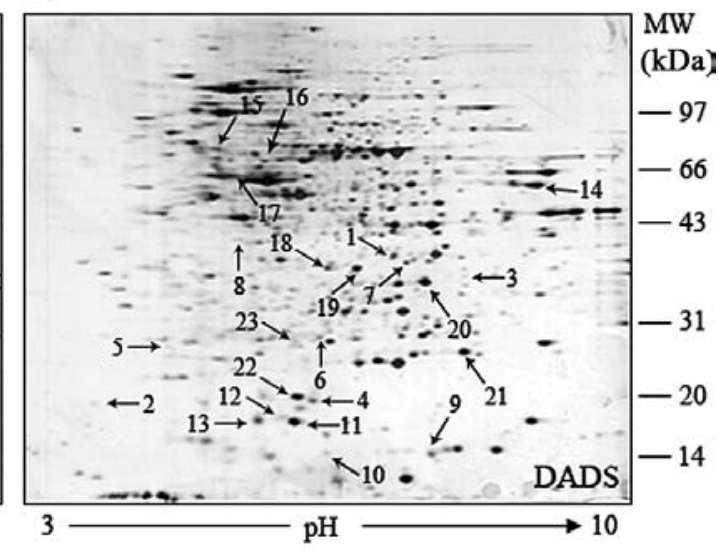

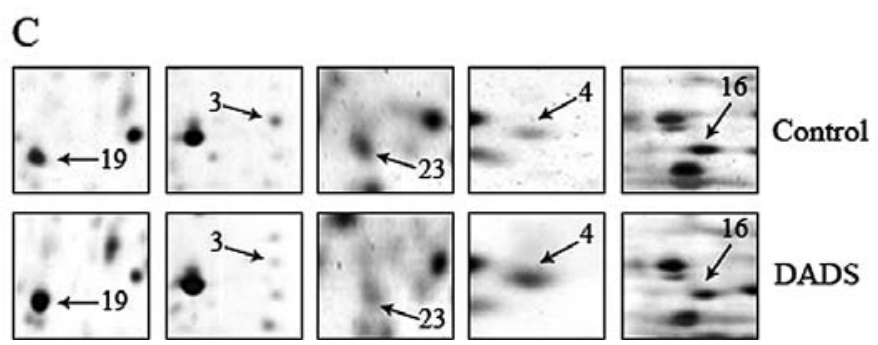

Figure 2. Two-dimensional gel analysis and MALDI-TOF-MS identification of differential expression proteins between untreated and DADS-treated MGC-803 cells. After the cells were treated or untreated with $30 \mathrm{mg} / \mathrm{l}$ DADS for $24 \mathrm{~h}$, proteins were extracted and separated by 2-DE. Twenty-three protein spots showing significantly differential expression were identified using MALDI-TOF-MS, and are marked with arrows. Representative 2-DE maps of (A) untreated and (B) DADS-treated MGC-803 cells are shown. (C) Images of five differential expression protein spots, spot 3 (uPAR), spot 4 (nM23), spot 16 (LIMK1), spot 19 $(\mathrm{ROR} \alpha)$ and spot 23 (CDK1), are shown between untreated and DADS-treated MGC-803 cells. MALDI-TOF-MS, matrix-assisted laser desorption/ionization time of flight mass spectrometer; DADS, diallyl disulfide; 2-DE, two-dimensional electrophoresis; uPAR, urokinase-type plasminogen activator receptor; LIMK1, LIM kinase-1; ROR $\alpha$, retinoid-related orphan nuclear receptor $\alpha$; CDK1, cyclin-dependent kinase-1.

invasion activities of MGC-803 cells. Our previous studies have demonstrated that $30 \mathrm{mg} / \mathrm{l}$ DADS is able to cause the arrest of the $\mathrm{G} / \mathrm{M}$ phase of the cell cycle and the growth inhibition of the gastric cancer cells (10) based on $\mathrm{IC}_{50}$ values for 
Table I. Differential expression proteins induced by DADS in MGC803 cells.

\begin{tabular}{|c|c|c|c|c|c|c|}
\hline $\begin{array}{l}\text { Spot } \\
\text { no. }\end{array}$ & $\begin{array}{l}\text { Accession } \\
\text { no. }^{\mathrm{a}}\end{array}$ & Protein name & $\operatorname{Mr}(\mathrm{Da}) / \mathrm{pI}$ & $\begin{array}{l}\text { Matched } \\
\text { peptides }\end{array}$ & $\begin{array}{c}\text { Sequence } \\
\text { coverage (\%) }\end{array}$ & $\begin{array}{l}\text { Expression } \\
\text { alteration }\end{array}$ \\
\hline 1 & Q30136 & HLA-DRB1 protein & $24901.0 / 7.22$ & 8 & 46 & Upregulated \\
\hline 2 & O60522 & Antigen NY-CO-45 & $85665.9 / 4.46$ & 12 & 21 & Downregulated \\
\hline 3 & Q03405 & $\begin{array}{l}\text { Urokinase-type plasminogen } \\
\text { activator receptor }\end{array}$ & $31263.6 / 6.01$ & 8 & 26 & Downregulated \\
\hline 4 & $\mathrm{P} 15531$ & Metastasis inhibition factor $\mathrm{nm} 23$ & 20411.6/7.06 & 10 & 51 & Upregulated \\
\hline 5 & O00429 & Dynamin-1-like protein & $81877.6 / 6.37$ & 19 & 25 & Downregulated \\
\hline 6 & O60602 & $\begin{array}{l}\text { Toll-like receptor } 5 / \text { Toll/interleukin-1 } \\
\text { receptor-like protein } 3\end{array}$ & $97692.0 / 6.21$ & 10 & 17 & Downregulated \\
\hline 7 & Q92782 & Zinc finger protein neuro-d4 & $39875.8 / 6.28$ & 7 & 28 & Downregulated \\
\hline 8 & Q08499 & Phosphodiesterase 4D & $76466.9 / 4.86$ & 8 & 15 & Downregulated \\
\hline 9 & P98088 & Mucin-5AC/gastric mucin & $91762.7 / 6.85$ & 35 & 40 & Upregulated \\
\hline 10 & Q86XL3 & $\begin{array}{l}\text { Ankyrin repeat and LEM } \\
\text { domain-containing protein } 2\end{array}$ & $87454.5 / 6.37$ & 21 & 29 & Downregulated \\
\hline 11 & P98170 & $\mathrm{X}$-linked inhibitor of apotosis protein & $56701.3 / 6.22$ & 7 & 26 & Downregulated \\
\hline 12 & P20062 & Transcobalamin-2 & $47535.3 / 6.52$ & 11 & 25 & Downregulated \\
\hline 13 & P33981 & Dual specificity protein kinase TTK & $95279.9 / 8.66$ & 26 & 31 & Upregulated \\
\hline 14 & $\mathrm{P} 40926$ & Malate dehydrogenase & $35531.5 / 8.92$ & 8 & 35 & Upregulated \\
\hline 15 & P52597 & $\begin{array}{l}\text { Heterogeneous nuclear } \\
\text { ribonucleoprotein } \mathrm{F}\end{array}$ & $45672.1 / 5.38$ & 6 & 23 & Downregulated \\
\hline 16 & P53667 & LIM kinase-1 & $83045.8 / 6.05$ & 7 & 14 & Downregulated \\
\hline 17 & Q14934 & Nuclear factor of activated T-cells & $95473.3 / 5.29$ & 11 & 19 & Downregulated \\
\hline 18 & Q99676 & Zinc finger protein 184 & $83269.5 / 8.50$ & 12 & 26 & Upregulated \\
\hline 19 & P35398 & Nuclear receptor ROR $\alpha$ & $63036.2 / 5.97$ & 10 & 16 & Upregulated \\
\hline 20 & $\mathrm{P} 01850$ & T-cell receptor $\beta-1$ chain $\mathrm{C}$ region & $34440.2 / 6.23$ & 5 & 31 & Upregulated \\
\hline 21 & P78536 & TNF- $\alpha$-converting enzyme & $92961.5 / 5.59$ & 9 & 14 & Downregulated \\
\hline 22 & Q9UNN8 & Endothelial protein $\mathrm{C}$ receptor & $26641.6 / 6.70$ & 5 & 33 & Upregulated \\
\hline 23 & P06493 & Cyclin-dependent kinase 1/CDC2 & $27502.9 / 6.54$ & 5 & 11 & Downregulated \\
\hline
\end{tabular}

${ }^{\text {aS }}$ wiss-Prot accession number; ${ }^{\mathrm{b}}$ spot intensity $\geq 2$-fold increased or decreased in DADS-treated group in comparison with untreated group. DADS, diallyl disulfide; ROR $\alpha$, nuclear receptor $\alpha$.

DADS (17). Thus, incubation with $30 \mathrm{mg} / \mathrm{l}$ DADS was used in the subsequent experiments.

Identification of differential expression proteins by 2-DE and $M S$. To analyze the differential expression proteins induced by DADS in gastric cancer MGC-803 cells, the cells were treated with $30 \mathrm{mg} / 1$ DADS for $24 \mathrm{~h}$. The proteins from DADS-treated and untreated cells were resolved by 2-DE respectively, and the gels were stained with silver to visualize the protein spots in the 2-DE gels. Two representative 2-DE maps from DADS-treated and untreated group are shown in Fig. 2A and B, respectively. By comparing the ratio of each spot in the gels, 291 protein spots that had consistent differences ( $\geq 2$-fold) between DADStreated group and the untreated group in triplicate experiments were considered as differentially expressed. Among them, 23 selected differential protein spots were excised from the stained gels, subjected to trypsin digestion. Twenty-three differentially expressed proteins were identified based on MALDI-TOF-MS and database query with MS-Fit (Table I). These protein spots are marked with arrows in Fig. 2A and B.
Compared with the untreated group, the expression levels of 9 proteins were increased, whereas the expression levels of the other 14 proteins were decreased in DADS-treated group.

Verification of DADS-induced differential expression genes in MGC-803 cells. Among the identified proteins, $\mathrm{ROR} \alpha, \mathrm{nM} 23$, LIMK1, uPAR and CDK1 displayed significantly differential expression in DADS-treated cells compared with the untreated cells. A representative comparison of the five proteins is shown in Fig. 2C. These five proteins were subjected to further validation. RT-PCR and western blot analysis were performed to explore the expression pattern of these five genes after the MGC-803 cells were exposed to $30 \mathrm{mg} / \mathrm{l}$ DADS for various times. As shown in Fig. 3A, the mRNA levels of ROR $\alpha$ and $\mathrm{nM} 23$ increased in a time-dependent manner. Whereas, LIMK1, uPAR and CDK1 mRNA levels decreased in a timedependent manner. Accordingly, similar changes in the protein levels were also observed in the MGC-803 cells upon DADS treatment (Fig. 3B). Therefore, changes in the gene expression induced by DADS were confirmed at the transcriptional and 
A
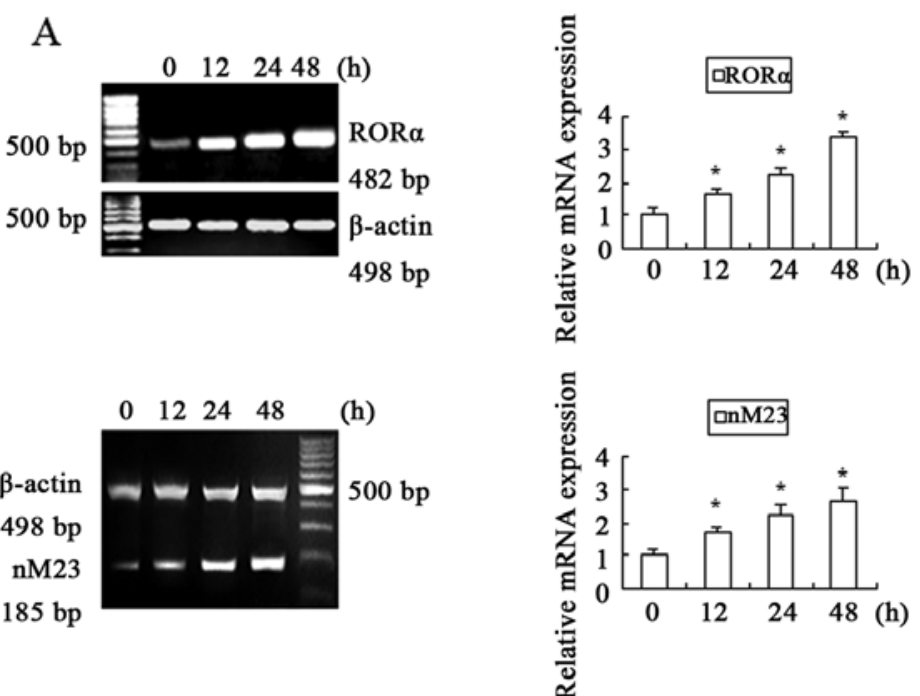

$\begin{array}{llll}0 & 24 & 48 & \text { (h) }\end{array}$
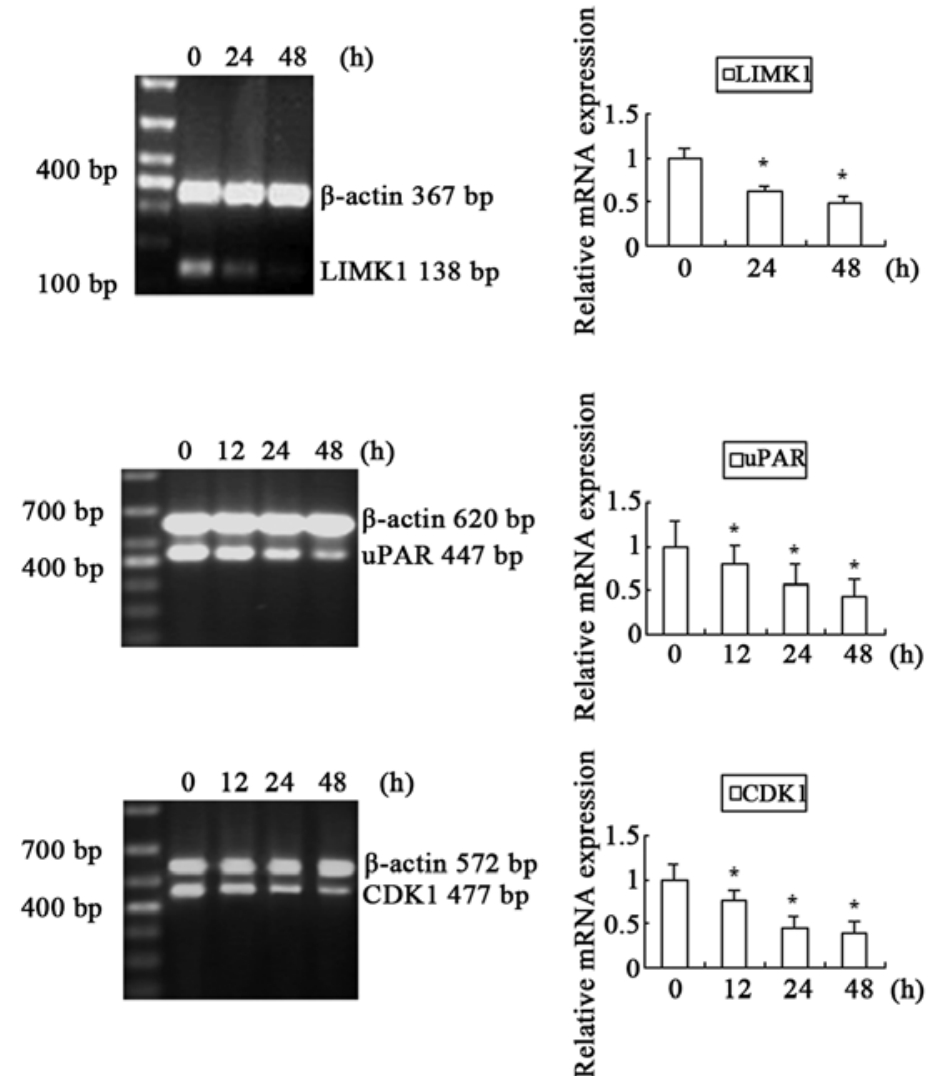

B

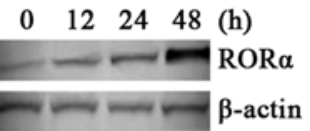

$\begin{array}{lllll}0 & 12 & 24 & 48 & (\mathrm{~h})\end{array}$
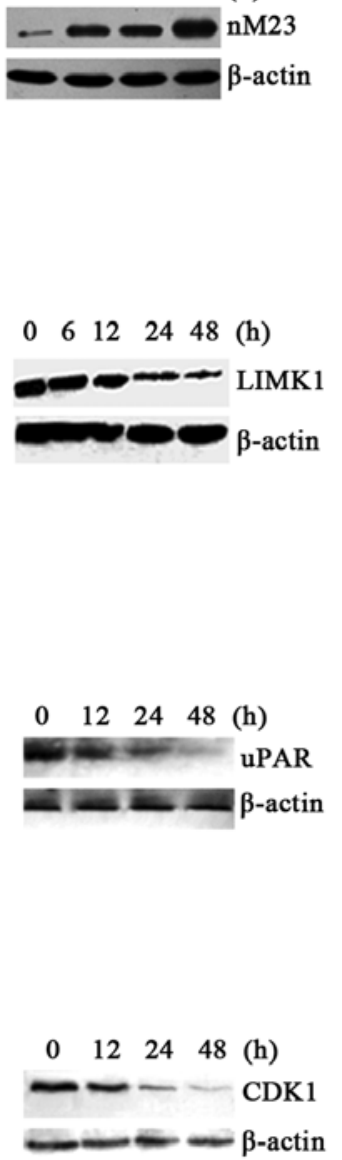
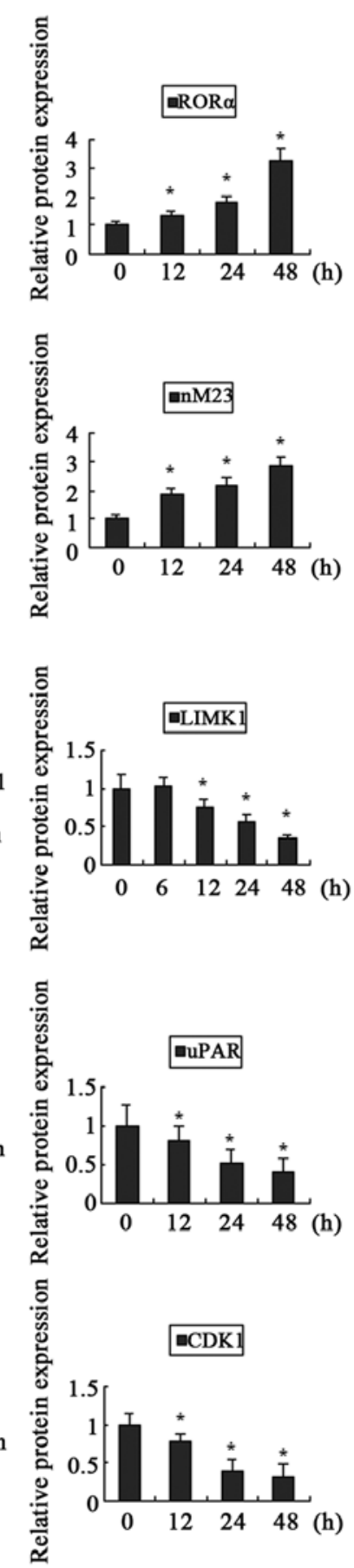

Figure 3. The genes with differential expression induced by DADS in the MGC-803 cells. The cells were exposed to 30 mg/1 DADS for indicated times. (A) The mRNA expression levels of ROR $\alpha, \mathrm{nM} 23$, LIMK1, uPAR and CDK1 were detected by RT-PCR. $\beta$-actin was used as an internal control for normalization. (B) Western blot analysis was used to determine the ROR $\alpha$, nM23, LIMK1, uPAR and CDK1 protein levels. $\beta$-actin was used as a loading control. The relative fold-changes in mRNA or the protein level compared with the controls were calculated. * $<<0.05$ vs. control. DADS, diallyl disulfide; ROR $\alpha$, retinoid-related orphan nuclear receptor $\alpha$; LIMK1, LIM kinase-1; uPAR, urokinase-type plasminogen activator receptor; CDK1, cyclin-dependent kinase-1.

translational levels, which were consistent with the results from the comparative proteomics research.

DADS inhibits the ERK/Fra-1 pathway through decreasing uPAR expression in MGC-803 cells. uPAR activates diverse cell signaling pathways, including the ERK/Fra-1 pathway. We hypothesized that the decreased expression of uPAR induced by DADS may cause inhibition of the ERK/Fra-1 pathway. To test this hypothesis, we first constructed several stable uPAR-interfering MGC-803 cell lines using microRNA (miR), and then chose miR3, which showed the most knockdown efficacy, for the following experiments (Fig. 4A). Then, we determined the levels of phosphorylated ERK1/2 in DADS-treated and uPARinterfering cells. As anticipated, knockdown of uPAR resulted in decreased levels of p-ERK1/2 (Fig. 4B). The levels of Fra-1 protein were also downregulated by DADS and knockdown 

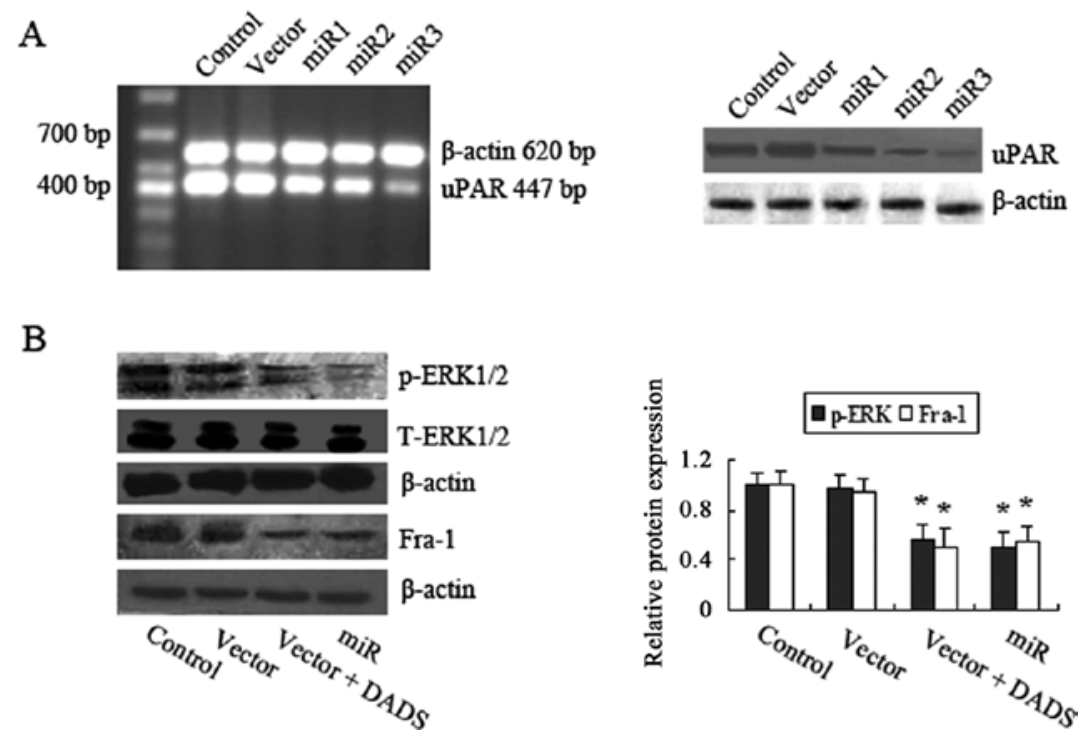

Figure 4. DADS blocks the ERK/Fra-1 pathway through decreasing uPAR expression in MGC803 cells. (A) The MGC803 cells were transfected with the uPAR-microRNA ( $\mathrm{miR} 1, \mathrm{miR} 2$ and $\mathrm{miR} 3$ ) or the empty vectors, and RT-PCR and western blotting were performed to detect the mRNA and protein expression levels of the uPAR. (B) p-ERK, total ERK and Fra-1 protein levels were determined by western blotting in uPAR-microRNA transfected and DADS-treated cells. $\beta$-actin was used as a loading control. The relative fold-changes in the protein level compared with the empty vector groups were calculated. " $\mathrm{P}<0.05$ vs. control or the empty vector group. DADS, diallyl disulfide; UPAR, urokinase-type plasminogen activator receptor.

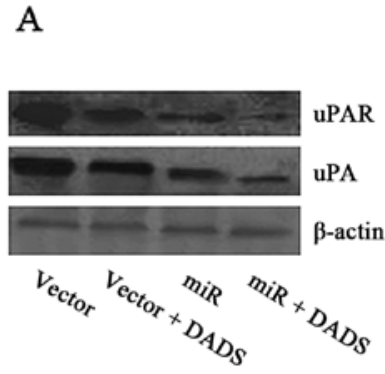

B

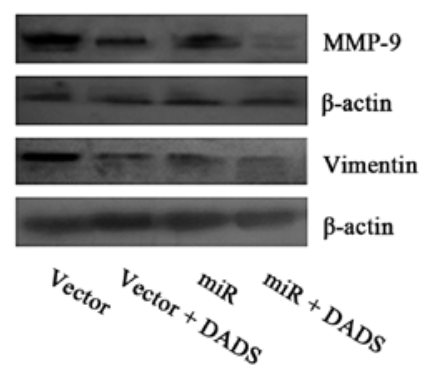

$\mathrm{C}$

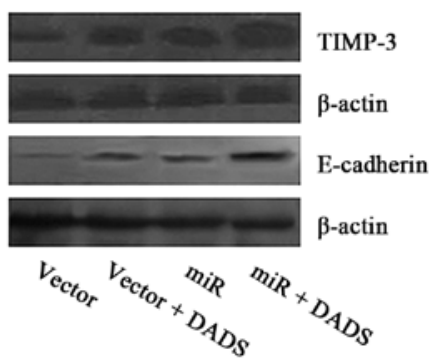

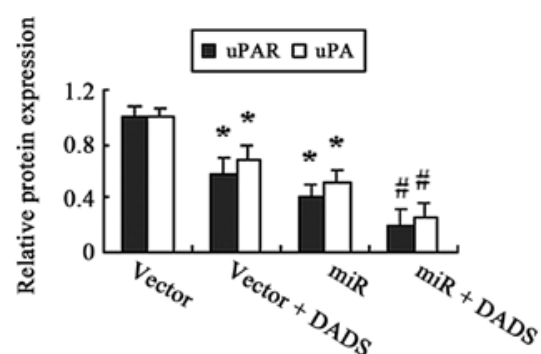
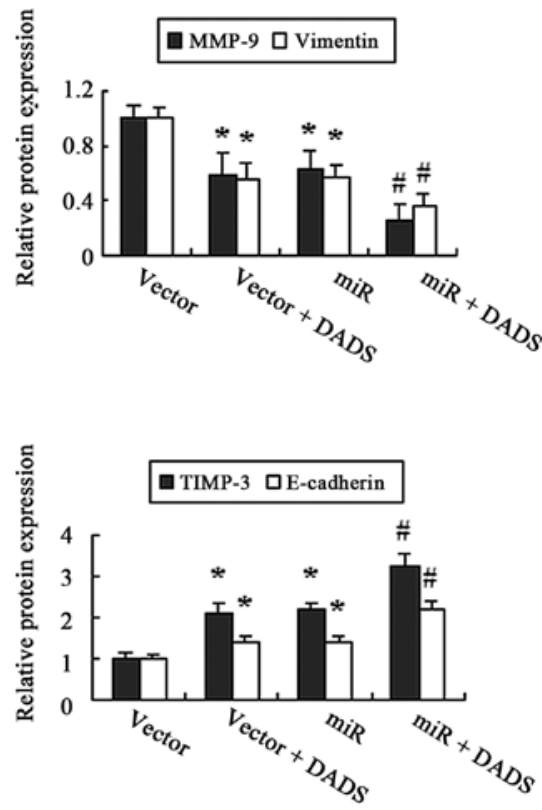

Figure 5. Downregulation of uPAR by DADS affects invasion and EMT-associated protein expression in MGC-803 cells. The cells transfected with uPAR-miR or the empty vector were treated or untreated with $30 \mathrm{mg} / 1$ DADS for $24 \mathrm{~h}$. The expression of uPAR, (A) uPA and MMP-9, (B) vimentin and TIMP-3, (C) and E-cadherin proteins were determined by western blot analysis. $\beta$-actin was used as a loading control. The relative fold-changes in the protein level compared with the empty vector groups (controls) were calculated. ${ }^{\mathrm{P}}<0.05$ vs. control, ${ }^{\#} \mathrm{P}<0.05$ vs. control, the uPAR-miR or the DADS group. uPAR, urokinase-type plasminogen activator receptor; DADS, diallyl disulfide; EMT, epithelial-mesenchymal transition; uPA, urokinase-type plasminogen activator; MMP-9, matrix metalloproteinase-9; TIMP-3, tissue inhibitor of metalloproteinase-3. 
A
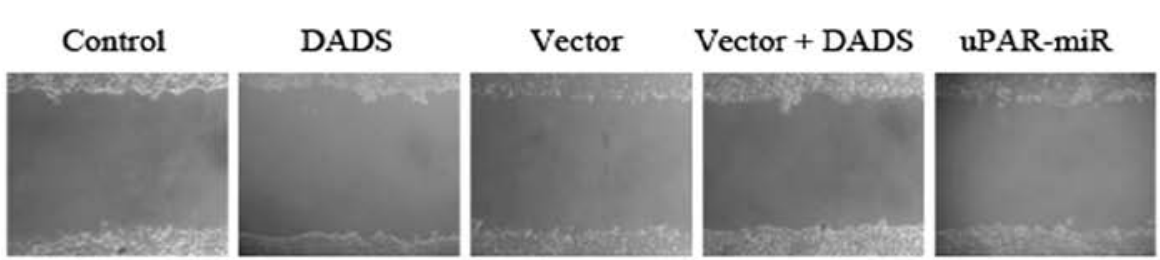

uPAR-miR
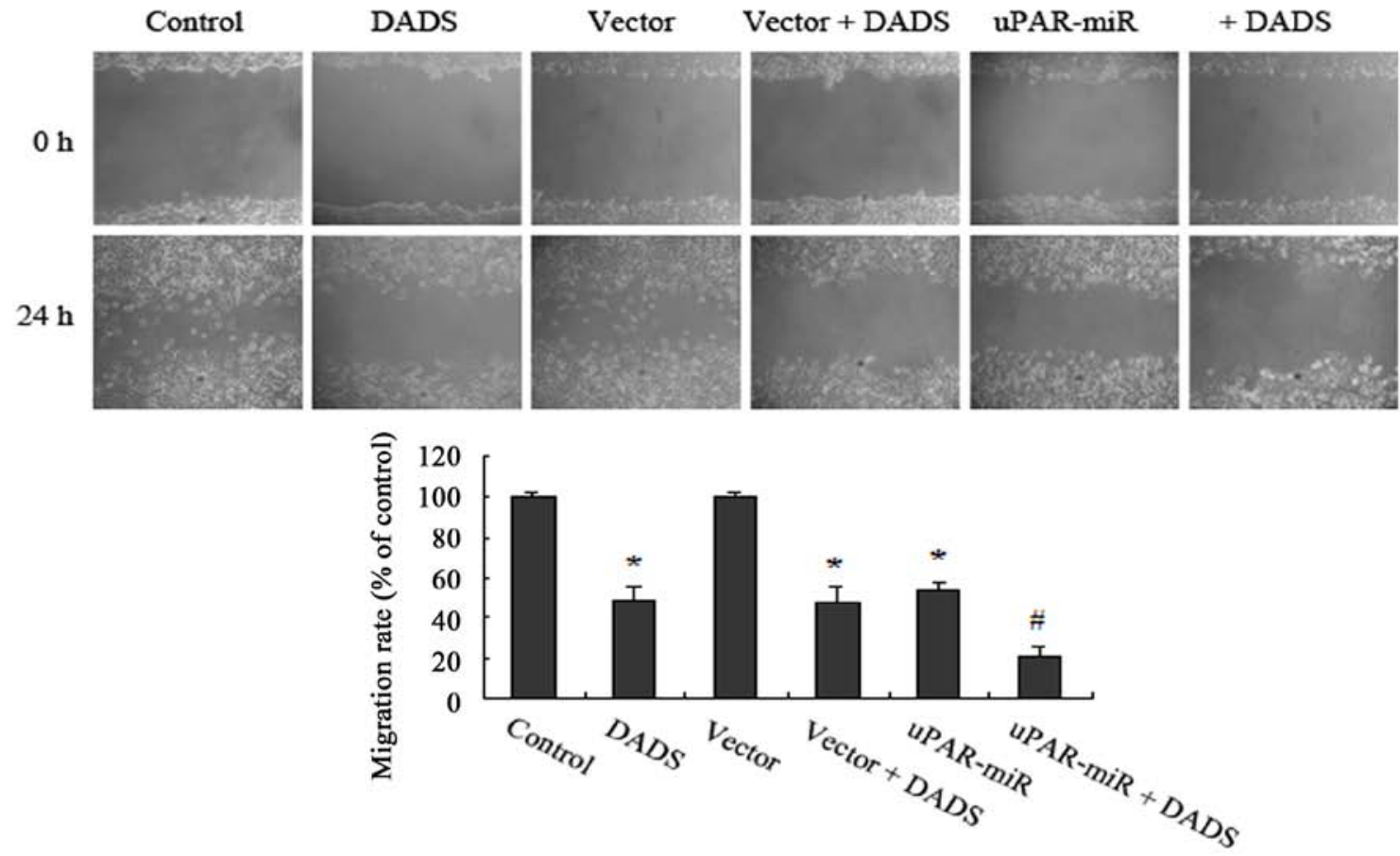

B
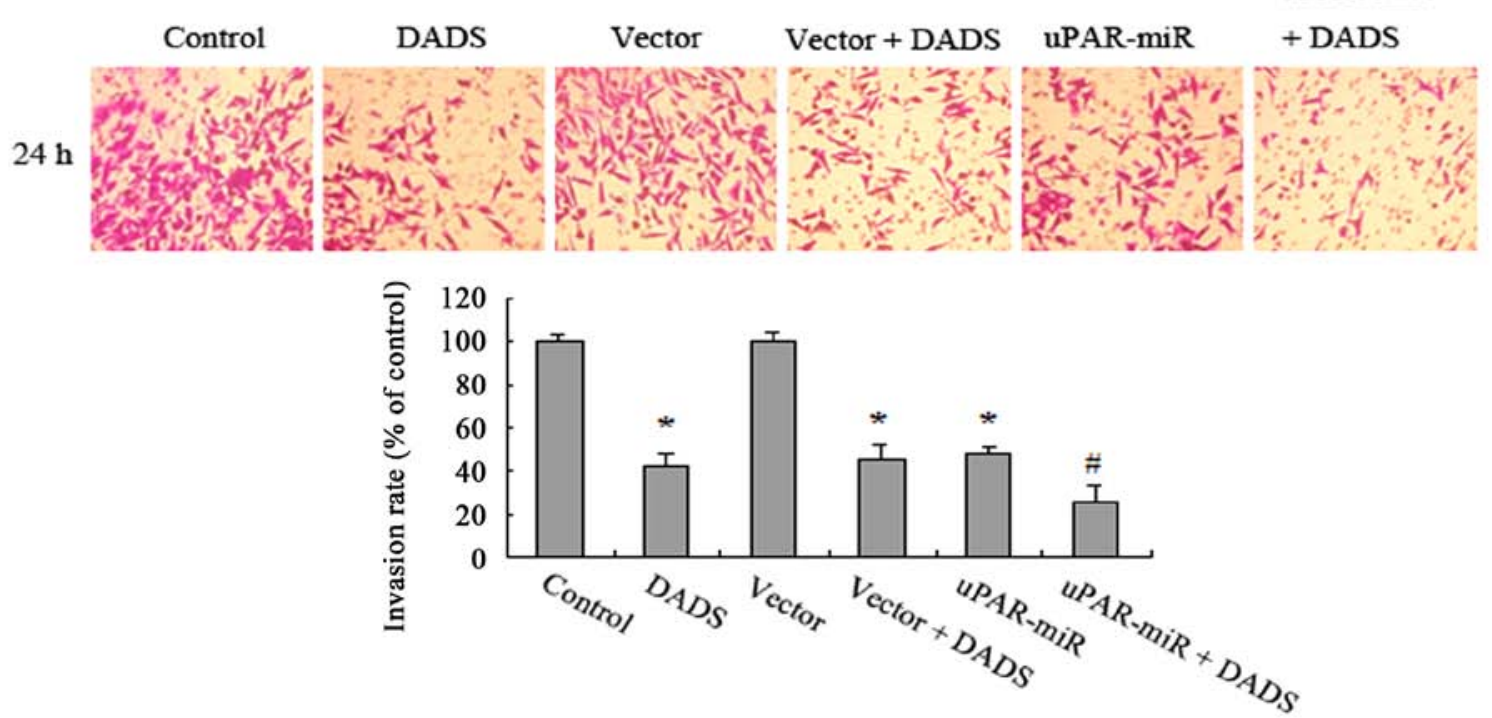

Figure 6. Downregulation of uPAR potentiates inhibitory effects of DADS on MGC-803 cell migration and invasion. The transfected or untransfected cells were treated or untreated with $30 \mathrm{mg} / \mathrm{DADS}$ for 0 and $24 \mathrm{~h}$. (A) Cell migration was analyzed using the scratch wound assay. The migration rate compared with the $0 \mathrm{~h}$ group was calculated. (B) The invasion rate compared with the $0 \mathrm{~h}$ group was determined. ${ }^{*} \mathrm{P}<0.05$ vs. control or the vector group, ${ }^{\prime \prime} \mathrm{P}<0.05$ vs. the vector group, the vector + DADS or the uPAR-miR groups. uPAR, urokinase-type plasminogen activator receptor; DADS, diallyl disulfide.

of uPAR (Fig. 4B). These data suggest that downregulation of UPAR by DADS inhibited ERK1/2 activities and Fra-1 expression, leading to blockage of ERK/Fra-1 pathway.

Downregulation of $u P A R$ by DADS affects invasion and EMT-associated protein expression in MGC-803 cells. Activation of the ERK/Fra-1 pathway is involved in positively regulating cancer cell invasion and EMT-related genes, such as UPA and MMP-9. Fig. 5A and B showed that uPA (urokinase-type plasminogen activator) and MMP-9 expression were attenuated by DADS, accompanied by downregulation of UPAR. Moreover, similar results were observed in the uPAR-interfering cells. Moreover, DADS upregulated TIMP-3 (tissue inhibitor of metalloproteinase-3) expression (Fig. 5C). Next, we examined the expression levels of vimentin and E-cadherin, which were taken as markers of EMT. Both DADS and knockdown of uPAR decreased the vimentin and increased the E-cadherin expression (Fig. 5B and C). Moreover, knockdown of uPAR is able to augment these effects induced by DADS (Fig. 5A-C). 
Downregulation of UPAR potentiates inhibitory effects of $D A D S$ on MGC-803 cell migration and invasion. To test whether DADS-induced downregulation of UPAR is responsible for inhibition of MGC-803 cell migration and invasion, we performed the scratch wound and invasion assays. The results showed that the migration rates of the cells after UPAR knockdown were obviously reduced in contrast to the vector group, as well as that of the DADS-treated cells in contrast to the control group (Fig. 6A). Moreover, both DADS-treated and uPAR knockdown cells exhibited a significant decrease in the invasion rates (Fig. 6B). In addition, stronger inhibitory effects on cell migration and invasion were found in the uPARinterfering cells exposed to DADS for $24 \mathrm{~h}$ (Fig. 6A and B).

\section{Discussion}

In the present study, we identified differentially expressed proteins induced by DADS in gastric cancer cells using the comparative proteomics technique. Among them, ROR $\alpha$, nM23, LIMK1, uPAR and CDK1 attracted our attention since dysregulation of their expression and function is closely correlated with tumorigenesis and progression, particularly invasion and metastasis. The effects of DADS on these gene expression have not yet been reported in the gastric cancer cells.

ROR $\alpha$ is a member of the orphan nuclear factor family that regulates gene expression by binding to ROR response elements. Its decreased expression is shown in cancers, suggesting that ROR $\alpha$ inactivation may be one mechanism underlying tumorigenesis (18). Activation of ROR $\alpha$ suppresses the expression of Wnt/B-catenin target genes, resulting in inhibition of proliferation and migration of colon cancer cells (19). ROR $\alpha$ inhibits breast cancer cell invasion by transactivation of SEMA3F, a suppressive microenvironmental factor (20). Thus, ROR $\alpha$ has been proposed to act as a tumor suppressor. In gastric cancer, methylation silence of the ROR $\alpha$ gene may be one reason for its inactivation (21). Our previous studies demonstrated that DADS could upregulate p21 expression through augmenting histone acetylation (22), we speculate that this epigenetic mechanism may be implicated in DADS-induced ROR $\alpha$ expression in MGC-803 cells, and upregulation of ROR $\alpha$ by DADS may contribute to its bioactivity against gastric cancer cell growth and invasion.

$\mathrm{Nm} 23$ is characterized as a specific metastasis suppressor ascribed to its multiple activities involving regulation of tumor metastatic process. The decreased Nm23 expression facilitates tumor cell motility and invasion, while its overexpression in aggressive cancer cells suppresses their metastatic capacity (23). Nm23 silencing promotes invadopodia formation, activation of pro-invasive signaling pathways and upregulation of MMPs (24). Whereas, re-expression of $\mathrm{Nm} 23$ attenuates metastatic ability of cancer cells by altering the expression of metastasis-related genes $(25,26)$. Therefore, effort has been made to develop agents to recover Nm23 function in cancer cells. For an example, lycopene reduces experimental tumor metastasis in vivo via increasing $\mathrm{Nm} 23$ protein expression (27). It has been reported that the decreased $\mathrm{Nm} 23$ protein level was observed in lymph node and liver metastases in contrast to primary lesions of gastric cancer (28). In the present study, our data indicated that DADS upregulates
$\mathrm{Nm} 23$ expression in gastric cancer cells. It suggests that restoration of nm 23 bioactivity may be a mechanism underlying DADS anti-invasion effect on gastric cancer cells.

LIM kinases (LIMK1 and LIMK2) are the common downstream effectors of Rho-ROCK, Rac-PAK and Cdc42-MRCK pathways that regulate rearrangements of actin cytoskeleton. Functional dysregulation of LIMKs, due to their overexpression and overactivation, in particular LIMK1 $(29,30)$, promotes the formation and maturation of matrix-degrading invadopodia, which facilitate cancer cell invasion (31). Whereas, knockdown of LIMK1 expression blocks invadopodia formation, and reduces MMP-9 expression and matrix protein degradation, decreasing the invasive potential of cancer cells (31). Our previous study demonstrated that the suppressive effects of DADS on colon cancer cell motility and invasiveness are associated with attenuating Rac1-Rock1/Pak1-LIMK1 signaling pathway (32). Thus, LIMK1 may be a candidate target for DADS against gastric cancer cell invasion.

uPAR is a glycolipid-anchored cell surface receptor. Its elevated expression indicates poor prognosis in many human tumors, including gastric cancer (33). In addition to mediating the degradation of extracellular matrix by its interaction with uPA to activate plasminogen and MMPs, uPAR interacts with co-receptors to activate intracellular signaling pathways (34). Furthermore, overactivation of uPAR-dependent signaling pathways fosters EMT and invasion, and these cellular changes are blocked by silencing uPAR (35) or uPA (36) expression. Since various signaling pathways are involved in inducing uPAR expression, which in turn stimulates gastric cancer cell invasiveness, uPAR has been considered as a potential therapeutic target (37). It has been demonstrated that ERK activation promotes the expression of the AP-1 family transcription factor Fra-1, which is essential for cell invasion through modulating invasion-associated gene expression, such as uPA and MMP-9 (38). The present study showed that DADS reduced UPAR expression in the MGC-803 cells, suggesting that a decrease in UPAR protein may lead to suppression of its downstream effectors of ERK/Fra-1, resulting in inhibition of cell migration and invasion. To testify this assumption, we examined effects of DADS on ERK/Fra-1 pathway and its target gene expression in MGC-803 cells. Our data showed that DADS decreased phosphorylation of ERK1/2 and Fra-1 expression, concomitant with the decreased expression of uPA and MMP-9. Additionally, DADS increased the expression of TIMP-3, which inhibits the catalytic activity of MMPs to maintain extracellular matrix (ECM) homeostasis. These changes resulting from DADS-induced downregulation of UPAR were supported by the similar results that were observed in UPAR knockdown cells. Notably, we found that DADS downregulates vimentin and upregulates E-cadherin expression, and these results were consistent with the observations in the UPAR knockdown cells. Recent researches indicated that overactivation of ERK/Fra-1 pathway induces EMT $(39,40)$, and Fra-1 is involved in regulation of the expression of vimentin (41) and E-cadherin (42). Based on these findings, we proposed that DADS may inhibit EMT in gastric cancer cells, which may partially account for its inhibitory effect on MGC-803 cell invasion. Notably, DADS is able to exert more potent effects on uPAR knockdown cells. We speculate that DADS-induced invasion inhibition may involve other mechanisms that remain 
to be revealed except for downregualtion of uPAR, such as inhibition of LIMK1 and upregulation of ROR $\alpha$ and $\mathrm{Nm} 23$.

CDK1 plays a critical role in promoting the transition of the $\mathrm{G} 2 / \mathrm{M}$ phase of the cell cycle through the formation of a complex between CDK1 and cyclin B1 or cyclin A. Its functional dysregulation results in tumor cell unlimited proliferation. Inhibition of CDK1 expression and activity is an effective approach to suppress tumor growth and sensitize cancer cells to apoptosis $(43,44)$. We previously reported that the decrease of CDK1 expression and its interaction with Mcl1 (an anti-apoptotic factor) are involved in the DADS-induced $\mathrm{G} 2 / \mathrm{M}$ phase arrest in human leukemia HL-60 cells (45). In the present study, we revealed that DADS reduces CDK1 expression in gastric cancer MGC-803 cells. It suggests that the inhibitory effect of DADS on CDK1 may contribute to the treatment of gastric cancer, since gastric tumor tissues show higher CDK1 expression and activity than non-neoplastic mucosa (46).

In summary, we revealed that DADS is able to increase ROR $\alpha$ and $n M 23$ expression and decrease LIMK1, uPAR and CDK1 expression. DADS-induced downregulation of UPAR is able to partially account for inhibition of the ERK/Fra-1 pathway, and migration and invasion of gastric MGC-803 cells. These findings are valuable for revealing potential targets for DADS, but further studies are required to demonstrate its antigastric cancer mechanisms.

\section{Acknowledgements}

The present study was supported by the National Natural Scientific Foundation of China (nos. 81374013, 31201027, 31100935, 81102854, 31000629 and 81100375), the Key Project Foundation of the Science and Technology program of Hunan Province of China (no. 04SK1004), the Patency Foundation of Innovation Platform of Hunan Provincial University of China (no. 09K074), the Key Project of Scientific Research Foundation of Hunan Province Education Department of China (no. 09A077), the Key Hunan Provincial Natural Science Foundation of China (no. 07JJ3033) and the Construct Program of the Key Discipline in Hunan Province of China (no. 2011-76).

\section{References}

1. Jemal A, Bray F, Center MM, Ferlay J, Ward E and Forman D: Global cancer statistics. CA Cancer J Clin 61: 69-90, 2011.

2. Yang L: Incidence and mortality of gastric cancer in China. World J Gastroenterol 12: 17-20, 2006.

3. Patel JN, Fuchs CS, Owzar K, Chen Z and McLeod HL: Gastric cancer pharmacogenetics: Progress or old tripe? Pharmacogenomics 14: 1053-1064, 2013.

4. Powolny AA and Singh SV: Multitargeted prevention and therapy of cancer by diallyl trisulfide and related Allium vegetablederived organosulfur compounds. Cancer Lett 269: 305-314, 2008.

5. Yi L and Su Q: Molecular mechanisms for the anti-cancer effects of diallyl disulfide. Food Chem Toxicol 57: 362-370, 2013.

6. Sundaram SG and Milner JA: Diallyl disulfide suppresses the growth of human colon tumor cell xenografts in athymic nude mice. J Nutr 126: 1355-1361, 1996.

7. Nakagawa H, Tsuta K, Kiuchi K, Senzaki H, Tanaka K, Hioki K and Tsubura A: Growth inhibitory effects of diallyl disulfide on human breast cancer cell lines. Carcinogenesis 22: 891-897, 2001.

8. Shin DY, Kim GY, Kim JI, Yoon MK, Kwon TK, Lee SJ, Choi YW, Kang HS, Yoo YH and Choi YH: Anti-invasive activity of diallyl disulfide through tightening of tight junctions and inhibition of matrix metalloproteinase activities in LNCaP prostate cancer cells. Toxicol In Vitro 24: 1569-1576, 2010.
9. Park HS, Kim GY, Choi IW, Kim ND, Hwang HJ, Choi YW and Choi YH: Inhibition of matrix metalloproteinase activities and tightening of tight junctions by diallyl disulfide in AGS human gastric carcinoma cells. J Food Sci 76: T105-T111, 2011.

10. Ling H, Wen L, Ji XX, Tang YL, He J, Tan H, Xia H, Zhou JG and Su Q: Growth inhibitory effect and Chk1-dependent signaling involved in $\mathrm{G}_{2} / \mathrm{M}$ arrest on human gastric cancer cells induced by diallyl disulfide. Braz J Med Biol Res 43: 271-278, 2010.

11. Bo S, Hui H, Li W, Hui L, Hong X, Lin D, Dai WX, Wu YH, Ai XH, Hao J, et al: Chk1, but not Chk2, is responsible for G2/M phase arrest induced by diallyl disulfide in human gastric cancer BGC823 cells. Food Chem Toxicol 68: 61-70, 2014.

12. Yuan JP, Wang GH, Ling H, Su Q, Yang YH, Song Y, Tang RJ, Liu Y and Huang C: Diallyl disulfide-induced G2/M arrest of human gastric cancer MGC803 cells involves activation of p38 MAP kinase pathways. World J Gastroenterol 10: 2731-2734, 2004.

13. Ling H, Zhang LY, Su Q, Song Y, Luo ZY, Zhou XT, Zeng X, $\mathrm{He}$ J, Tan $\mathrm{H}$ and Yuan JP: Erk is involved in the differentiation induced by diallyl disulfide in the human gastric cancer cell line MGC803. Cell Mol Biol Lett 11: 408-423, 2006.

14. Tang H, Kong Y, Guo J, Tang Y, Xie X, Yang L, Su Q and Xie X: Diallyl disulfide suppresses proliferation and induces apoptosis in human gastric cancer through Wnt-1 signaling pathway by up-regulation of miR-200b and miR-22. Cancer Lett 340: 72-81, 2013.

15. Gharahdaghi F, Weinberg CR, Meagher DA, Imai BS and Mische SM: Mass spectrometric identification of proteins from silver-stained polyacrylamide gel: A method for the removal of silver ions to enhance sensitivity. Electrophoresis 20: 601-605, 1999.

16. Su B, Xiang B, Wang L, Cao L, Xiao L, Li X, Li X, Wu M and Li G: Profiling and comparing transcription factors activated in non-metastatic and metastatic nasopharyngeal carcinoma cells. J Cell Biochem 109: 173-183, 2010.

17. Zhang LY, Ling H, Su Q, Song Y and Liang XQ: Inhibitory effect of diallyl disulfide on human gastric cancer cell line MGC803 in vitro. Shijie Huaren Xiaohua Zazhi 11: 1290-1293, 2003 (In Chinese).

18. Zhu Y, McAvoy S, Kuhn R and Smith DI: RORA, a large common fragile site gene, is involved in cellular stress response. Oncogene 25: 2901-2908, 2006.

19. Lee JM, Kim IS, Kim H, Lee JS, Kim K, Yim HY, Jeong J, Kim JH, Kim JY, Lee H, et al: RORalpha attenuates Wnt/beta-catenin signaling by PKCalpha-dependent phosphorylation in colon cancer. Mol Cell 37: 183-195, 2010.

20. Xiong G, Wang C, Evers BM, Zhou BP and Xu R: RORa suppresses breast tumor invasion by inducing SEMA3F expression. Cancer Res 72: 1728-1739, 2012.

21. Yamashita S, Tsujino Y, Moriguchi K, Tatematsu M and Ushijima T: Chemical genomic screening for methylation-silenced genes in gastric cancer cell lines using 5-aza-2'-deoxycytidine treatment and oligonucleotide microarray. Cancer Sci 97: 64-71, 2006.

22. Su B, Xiang SL, Su J, Tang HL, Liao QJ, Zhou YJ and Su Q: Diallyl disulfide increased histone acetylation and $\mathrm{p} 21^{\mathrm{WAF}}$ expression in human gastric cancer cells in vivo and in vitro. Biochem Pharmacol 1: 1-10, 2012.

23. Marino N, Nakayama J, Collins JW and Steeg PS: Insights into the biology and prevention of tumor metastasis provided by the $\mathrm{Nm} 23$ metastasis suppressor gene. Cancer Metastasis Rev 31: 593-603, 2012.

24. Boissan M, De Wever O, Lizarraga F, Wendum D, Poincloux R, Chignard N, Desbois-Mouthon C, Dufour S, Nawrocki-Raby B, Birembaut $\mathrm{P}$, et al: Implication of metastasis suppressor NM23-H1 in maintaining adherens junctions and limiting the invasive potential of human cancer cells. Cancer Res 70: 7710-7722, 2010.

25. Che G, Chen J, Liu L, Wang Y, Li L, Qin Y and Zhou Q: Transfection of $\mathrm{nm} 23-\mathrm{H} 1$ increased expression of beta-catenin, E-cadherin and TIMP-1 and decreased the expression of MMP-2, CD44v6 and VEGF and inhibited the metastatic potential of human non-small cell lung cancer cell line L9981. Neoplasma 53: 530-537, 2006.

26. Horak CE, Mendoza A, Vega-Valle E, Albaugh M, GraffCherry C, McDermott WG, Hua E, Merino MJ, Steinberg SM, Khanna C, et al: Nm23-H1 suppresses metastasis by inhibiting expression of the lysophosphatidic acid receptor EDG2. Cancer Res 67: 11751-11759, 2007.

27. Huang CS, Liao JW and Hu ML: Lycopene inhibits experimental metastasis of human hepatoma SK-Hep-1 cells in athymic nude mice. J Nutr 138: 538-543, 2008. 
28. Guan-Zhen Y, Ying C, Can-Rong N, Guo-Dong W, Jian-Xin Q and Jie-Jun W: Reduced protein expression of metastasis-related genes (nm23, KISS1, KAI1 and p53) in lymph node and liver metastases of gastric cancer. Int J Exp Pathol 88: 175-183, 2007.

29. Bernard O: Lim kinases, regulators of actin dynamics. Int J Biochem Cell Biol 39: 1071-1076, 2007.

30. Wang W, Mouneimne G, Sidani M, Wyckoff J, Chen X, Makris A, Goswami S, Bresnick AR and Condeelis JS: The activity status of cofilin is directly related to invasion, intravasation, and metastasis of mammary tumors. J Cell Biol 173: 395-404, 2006.

31. Scott RW, Hooper S, Crighton D, Li A, König I, Munro J, Trivier E, Wickman G, Morin P, Croft DR, et al: LIM kinases are required for invasive path generation by tumor and tumorassociated stromal cells. J Cell Biol 191: 169-185, 2010.

32. Zhou Y, Su J, Shi L, Liao Q and Su Q: DADS downregulates the Rac1-ROCK1/PAK1-LIMK1-ADF/cofilin signaling pathway, inhibiting cell migration and invasion. Oncol Rep 29: 605-612, 2013

33. Laufs S, Schumacher J and Allgayer H: Urokinase-receptor (u-PAR): An essential player in multiple games of cancer: A review on its role in tumor progression, invasion, metastasis, proliferation/dormancy, clinical outcome and minimal residual disease. Cell Cycle 5: 1760-1771, 2006.

34. Smith HW and Marshall CJ: Regulation of cell signalling by uPAR. Nat Rev Mol Cell Biol 11: 23-36, 2010.

35. Lester RD, Jo M, Montel V, Takimoto S and Gonias SL: uPAR induces epithelial-mesenchymal transition in hypoxic breast cancer cells. J Cell Biol 178: 425-436, 2007.

36. Jo M, Lester RD, Montel V, Eastman B, Takimoto S and Gonias SL: Reversibility of epithelial-mesenchymal transition (EMT) induced in breast cancer cells by activation of urokinase receptor-dependent cell signaling. J Biol Chem 284: 22825-22833, 2009.

37. Ma YY and Tao HQ: Role of urokinase plasminogen activator receptor in gastric cancer: A potential therapeutic target. Cancer Biother Radiopharm 27: 285-290, 2012.

38. Belguise K, Kersual N, Galtier F and Chalbos D: FRA-1 expression level regulates proliferation and invasiveness of breast cancer cells. Oncogene 24: 1434-1444, 2005.
39. Diesch J, Sanij E, Gilan O, Love C, Tran H, Fleming NI, Ellul J, Amalia M, Haviv I, Pearson RB, et al: Widespread FRA1-dependent control of mesenchymal transdifferentiation programs in colorectal cancer cells. PLoS One 9: e88950, 2014.

40. Huang XY, Ke AW, Shi GM, Zhang X, Zhang C, Shi YH, Wang XY, Ding ZB, Xiao YS, Yan J, et al: $\alpha \mathrm{B}$-crystallin complexes with $14-3-3 \zeta$ to induce epithelial-mesenchymal transition and resistance to sorafenib in hepatocellular carcinoma. Hepatology 57: 2235-2247, 2013.

41. Andreolas C, Kalogeropoulou M, Voulgari A and Pintzas A: Fra-1 regulates vimentin during Ha-RAS-induced epithelial mesenchymal transition in human colon carcinoma cells. Int J Cancer 122: 1745-1756, 2008

42. Andersen H, Mejlvang J, Mahmood S, Gromova I, Gromov P, Lukanidin E, Kriajevska M, Mellon JK and Tulchinsky E: Immediate and delayed effects of E-cadherin inhibition on gene regulation and cell motility in human epidermoid carcinoma cells. Mol Cell Biol 25: 9138-9150, 2005.

43. Mayes PA, Dolloff NG, Daniel CJ, Liu JJ, Hart LS, Kuribayashi K, Allen JE, Jee DI, Dorsey JF, Liu YY, et al: Overcoming hypoxiainduced apoptotic resistance through combinatorial inhibition of GSK-3 $\beta$ and CDK1. Cancer Res 71: 5265-5275, 2011.

44. Wu W, Ye H, Wan L, Han X, Wang G, Hu J, Tang M, Duan X, Fan $\mathrm{Y}, \mathrm{He} \mathrm{S}$, et al: Millepachine, a novel chalcone, induces $\mathrm{G}_{2} / \mathrm{M}$ arrest by inhibiting CDK1 activity and causing apoptosis via ROS-mitochondrial apoptotic pathway in human hepatocarcinoma cells in vitro and in vivo. Carcinogenesis 34: 1636-1643, 2013.

45. Yi L, Ji XX, Tan H, Feng MY, Tang Y, Wen L and Su Q: Involvement of Mcl1 in diallyl disulfide-induced G2/M cell cycle arrest in HL-60 cells. Oncol Rep 27: 1911-1917, 2012.

46. Yasui W, Ayhan A, Kitadai Y, Nishimura K, Yokozaki H, Ito H and Tahara E: Increased expression of p34cdc2 and its kinase activity in human gastric and colonic carcinomas. Int J Cancer 53: 36-41, 1993. 